\title{
Sensitization of Bacterial Spores to Lysozyme and to Hydrogen Peroxide with Agents which Rupture Disulphide Bonds
}

\author{
By G. W. GOULD and A. D. HITCHINS \\ Unilever Research Laboratory, Colworth House, Sharnbrook, Bedford
}

(Received 10 June 1963)

\begin{abstract}
SUMMARY
Spores of Bacillus and Clostridium species were subjected to oxidizing and reducing agents known to rupture protein disulphide bonds and to irradiation (ultraviolet; high speed electron). These treatments caused no loss of brightness of spores when viewed by phase-contrast microscopy. However, lysozyme or hydrogen peroxide caused phase darkening of treated spores and loss of dipicolinic acid typical of normal germination except that hydrogen peroxide eventually caused almost complete lysis of the spores. Under certain conditions, spore viability was unaffected during treatment with reducing agents and during subsequent phase darkening in lysozyme. Spores made susceptible to lysozyme by reducing agents became insusceptible after storage in aerated water. These reactions are compatible with Vinter's observation of the high content of disulphide bonds in the coat fraction of spores (Vinter, 1960) and with the chemical or physical rupture of these bonds. Rupture of disulphide bonds allows action of lysozyme or hydrogen peroxide on previously protected substrates. The disulphide bonds are therefore probably important in the resistance of spores to enzymes and irradiation, and rupture of these bonds may be involved in the germination process. The probable location of the lysozyme substrate in mucopeptide of the spore cortex indicates the importance of the integrity of cortex structure in maintaining the phase brightness of spores.
\end{abstract}

\section{IN'TRODUCTION}

Bacterial endospores are dormant cells which are typically more resistant to desiccation, heat, toxic chemicals and ultraviolet irradiation than the corresponding vegetative forms. Spores germinate in solutions of specific metabolites such as L-alanine, inosine and glucose. Germination is characterized by rapid loss of resistance as above and the onset of metabolism. During germination several welldefined changes occur; these were reviewed by Murrell (1961). For instance, germinating spores shed mucopeptides, calcium and dipicolinic acid and become permeable to stains. At the same time the optical density of suspensions of germinating spores decreases by about $50 \%$ and in the phase-contrast microscope the initially bright spores become dark. This phase darkening is thought to correspond with an increase in spore hydration (Ross \& Billing, 1957). The dipicolinic acid and calcium in spores have been implicated in maintaining resistance of these cells to heat, but no function has been yet suggested for the mucopeptide. The mucopeptide shed by germinating spores is sensitive to lysozyme, although to our 
knowledge intact spores have never been shown to be attacked by lysozyme or any other enzyme. Many bacteria contain lysozyme-sensitive mucopeptide and yet are resistant to lysis by this enzyme; however, in some instances these resistant organisms may be made sensitive to lysozyme by various pretreatments such as incubation at low pH values (Noller \& Hartsell, 1961), freezing and thawing (Kohn, 1960), incubation with Versene (Repaske, 1956) or with acetone (Warren, Gray \& Bartell, 1955). It seemed possible that in spores, the lysozyme-sensitive mucopeptide might similarly be protected in some way. Spores of species of Bacillus contain a higher concentration of cystine disulphide bonds than the corresponding vegetative forms and most of these bonds are localized in the spore coat fractions (Vinter, 1960; $1961 a, b ; 1962$ ), which also contain protein (Salton \& Marshall, 1959; Ohye \& Murrell, 1962). This occurrence together of protein and high content of disulphide bonds suggested that spore coats may contain a keratin-like component and that the resistance of spores to the action of lysozyme might be due to the protective role of the disulphide-rich protein coat. We therefore subjected spores to chemical and physical treatments known to rupture protein disulphide bonds, to find whether these treatments rendered spores sensitive to lysozyme and other enzymes. Phase-contrast microscopy was used to detect lysis or change in spore morphology and refractility as a result of enzyme action. Phase darkening of treated spores was induced by lysozyme, and it was noticed that hydrogen peroxide had a similar effect. The action of hydrogen peroxide and lysozyme was therefore investigated. A preliminary account of these reactions was reported earlier (Gould \& Hitchins, 1963).

\section{ME'THODS}

Spore suspensions. The organism mainly used was Bacillus cereus NCTC 945; 18 other organisms used are listed in Results. Culture conditions and preparation of aerobic spore suspensions were as previously described (Hitchins, Gould \& Hurst, 1963). Anaerobic organisms were grown at $30^{\circ}$ in reinforced clostridial medium (Gibbs \& Hirsch, 1956). When sporulation was complete, spores were cleaned as referred to above and, when necessary, incubated with $1 \%(\mathrm{w} / \mathrm{v})$ trypsin (Hopkins and Williams, Ltd., Chadwell Heath, Essex) at $\mathrm{pH} \mathbf{8 \cdot 0}$ and $\mathbf{3 7 ^ { \circ }}$ for $\mathbf{1} \mathrm{hr}$. to dissolve cytoplasmic debris. After incubation with trypsin, spores were washed as above. Spore suspensions were stored in water at $4^{\circ}$.

Treatment of spores with agents which rupture disulphide bonds. The oxidizing agent used was performic acid $(2 \cdot 5-25 \%$, w/v), made just before use by mixing $95 \mathrm{ml}$. formic acid with $5 \mathrm{ml}$. $100 \mathrm{vol}$. hydrogen peroxide and incubating at room temperature for $2 \mathrm{hr}$. (Sanger, 1947). Reducing agents used were thioglycollic (mercaptoacetic) acid (1 to $25 \%$, w/v; Sela, White \& Anfinsen, 195\%); 2-mercapto-ethanol $(10 \% \mathrm{w} / \mathrm{v})$ in the presence of $8 \mathrm{M}$-urea (Epstein \& Anfinsen, 1962); sodium sulphite $(12.5 \%, \mathrm{w} / \mathrm{v})$ in the presence of $0.05 \mathrm{M}$-cuprammonium ion and $8 \mathrm{M}$-urea (Swan, 1957). Formic acid $(2 \cdot 5-25 \%, v / v)$ and hydrochloric acid $(0 \cdot 1 \%, v / v)$ were used as controls. Unless otherwise stated the reagents were used at their natural $\mathrm{pH}$ values. The physical agents used were ultraviolet radiation and high-speed electrons. Spore suspensions (in layers $0.5 \mathrm{~cm}$. deep) were exposed for 10 and $60 \mathrm{~min}$. in Petri dishes $10 \mathrm{~cm}$. away from a $30 \mathrm{~W}$. ultraviolet 'Chromatolite' (Hanovia Lamps, Slough) with the Wood's glass filter removed. Spore suspensions 
(about $0.5 \mathrm{~cm}$. thick) were also exposed in polythene sachets to irradiation by electrons from a linear accelerator at dose values of 0.5-20 Mrad. After incubation or irradiation the spores were washed once with cold water by centrifugation.

Re-oxidation of thioglycollic acid or 2-mercapto-ethanol treated spores. Spores treated with reducing agents were re-oxidized by dialysing $5 \mathrm{ml}$. of suspension against 1 l. water, with stirring, for up to 2 weeks (Isemura, Takagi, Maeda \& Imai, 1961).

Enzyme and hydrogen peroxide treatment of spores after exposure to agents which rupture disulphide bonds. After oxidation, reduction, re-oxidation or irradiation, washed spores were suspended at a concentration of about $10^{7} / \mathrm{ml}$. in various buffers at $37^{\circ}$. Enzymes or hydrogen peroxide were included in these mixtures at the following concentrations: trypsin (Hopkins \& Williams, Ltd.) and $\alpha$-chymotrypsin (C. F. Boehringer and Soehne, GmbH, Mannheim) $1 \%(\mathrm{w} / \mathrm{v})$ in $\mathbf{M} / \mathbf{1 5}$ phosphate buffer (pH 8.0); pepsin (crystalline, L. Light and Co. Ltd., Colnbrook), $1 \%(\mathrm{w} / \mathrm{v})$ in $0.02 \mathrm{~N}-\mathrm{HCl}$; peptidases (hog intestinal mucosa extract, L. Light and Co. Ltd.), $1 \%(\mathrm{w} / \mathrm{v})$ in $\mathrm{M} / \mathbf{1 5}$ phosphate buffer $(\mathrm{pH} 6 \cdot 0,8 \cdot 0)$; papain (Hopkins and Williams, Ltd), $1 \%(\mathrm{w} / \mathrm{v})$ with cysteine as activator (Fruton \& Simmonds, 1958) in M/15 phosphate buffer ( $\mathrm{pH} 8.0$ ); lysozyme (crystalline from egg white, L. Light and Co. Ltd.), 5-500 $\mu \mathrm{g} . / \mathrm{ml}$. in $\mathrm{M} / 15$ phosphate buffer ( $\mathrm{pH} \mathrm{8.0)}$; hydrogen peroxide (Hopkins and Williams Ltd.), 0.04-4 $\mathrm{M}$ in $\mathrm{M} / \mathbf{1 5}$ phosphate buffer ( $\mathrm{pH} \mathrm{8.0)}$.

Buffers, sequestrants and salts of metals. The following buffers were used (Mackie \& McCartney, 1960): phosphate (M/15) pH 6.0-8.0; McIlvaine (M/10) pH 2.6-7.0; carbonate + bicarbonate $(\mathrm{M} / 20) \mathrm{pH} \mathrm{9 \cdot 2-10 \cdot 6}$; tris $(\mathrm{M} / 20) \mathrm{pH} 8 \cdot 0$ and $9 \cdot 0$; carbonate + sodium hydroxide $(\mathrm{M} / \mathbf{2 0}) \mathrm{pH} \mathbf{1 1 \cdot 2}$. Ethylene diaminetetra-acetic acid $(7 \mathrm{~mm})$ was adjusted to $\mathrm{pH} 8.0$ with sodium hydroxide. The following salts of metals were used at $200 \mu \mathrm{M}: \mathrm{CuSO}_{4} ; \mathrm{CoCl}_{2} ; \mathrm{NiCl}_{2} ; \mathrm{MnSO}_{4} ; \mathrm{ZnSO}_{4} ; \mathrm{FeSO}_{4} .\left(\mathrm{NH}_{4}\right)_{2} \mathrm{SO}_{4} ; \mathrm{FeCl}_{3}$.

Optical examination of spores. About 250 spores were examined by phase-contrast microscopy for each estimation and the percentage of spores which showed phase darkening was recorded to the nearest $5 \%$. Optical densities of spore suspensions were measured at $580 \mathrm{~m} \mu$ in a Biochem absorptiometer (Hilger and Watts, Ltd., Camden Road, London, N.W. 1). These methods were used to estimate the extent of germination-like changes in spore suspensions.

Viability of spores. The ability of treated spores to germinate and produce colonies was tested in yeast glucose agar. Spores were mixed with reagents or lysozyme and samples withdrawn at intervals, immediately diluted, mixed with melted agar, incubated at $37^{\circ}$ and the colonies were later counted.

Estimation of dipicolinic acid (DPA). The DPA content of spores was measured by the colorimetric method of Jansen, Lund \& Anderson (1958).

\section{RESULTS}

Sensitization of spores to lysozyme. Bacterial spores appear bright under phasecontrast illumination and become dark during normal germination. Table 1 shows that after treatment with reagents known to oxidize or reduce protein disulphide bonds, although remaining phase bright, the spores became susceptible to lysozyme. Control treatments with formic or hydrochloric acids did not render spores susceptible to lysozyme; untreated spores were also not susceptible. Sensitivity to 
lysozyme was revealed by the phase darkening of oxidized and reduced spores in the presence of this enzyme; this phase darkening differed from the typical darkening of normal germination only because it obviously affected the peripheral region of the spore first. It is clear from Table 1 that sensitivity to lysozyme increased with the concentration of reagent, with reaction time and with temperature; the presence of urea also increased the sensitivity. Concentrations of lysozyme between 5 and $500 \mu \mathrm{g} . / \mathrm{ml}$. were effective, and the maximum rate of phase darkening occurred at about $100 \mu \mathrm{g} . / \mathrm{ml}$. Untreated spores were unaffected by lysozyme; for instance,

Table 1. Influence of chemical treatments on the sensitivity of Bacillus cereus spores to lysozyme

Treated spores were incubated at $37^{\circ}$ in $\mathrm{pH} 8.0$ phosphate buffer containing $100 \mu \mathrm{g}$. lysozyme $/ \mathrm{ml}$. Before incubation less than $5 \%$ spores were phase dark.

\begin{tabular}{|c|c|c|c|c|c|}
\hline \multicolumn{4}{|c|}{ Treatment } & \multicolumn{2}{|c|}{$\begin{array}{l}\text { Phase dark spores }(\%) \\
\text { in lysozyme after }\end{array}$} \\
\hline Reagent & $\begin{array}{l}\text { Concentra- } \\
\text { tion } \%(v / v)\end{array}$ & $\begin{array}{l}\text { Time } \\
\text { (hr.) }\end{array}$ & $\begin{array}{l}\text { Tempera- } \\
\text { ture }\left({ }^{\circ}\right)\end{array}$ & $15 \mathrm{~min}$. & $1 \mathrm{hr}$. \\
\hline \multirow[t]{8}{*}{ Performic acid } & 25 & $1 \cdot 0$ & 4 & $<5$ & $<5$ \\
\hline & 25 & 20 & 4 & 80 & $>95$ \\
\hline & 25 & 0.25 & 37 & 40 & 85 \\
\hline & 25 & $0 \cdot 5$ & 37 & 50 & $>95$ \\
\hline & 25 & $1 \cdot 0$ & 37 & 90 & $>95$ \\
\hline & 10 & $1 \cdot 0$ & 37 & 90 & $>95$ \\
\hline & $\mathbf{5}$ & $1 \cdot 0$ & 37 & 75 & 90 \\
\hline & $2 \cdot 5$ & $1 \cdot 0$ & 37 & 10 & 25 \\
\hline Formic acid & 25 & $1 \cdot 0$ & 37 & $<5$ & $<5$ \\
\hline \multirow[t]{5}{*}{ Thioglycollic acid } & 25 & 0.5 & 70 & $>95$ & $>95$ \\
\hline & 10 & $0 \cdot 5$ & 70 & 70 & 95 \\
\hline & $\mathbf{2 \cdot 5}$ & $0 \cdot 5$ & 70 & $\mathbf{5 0}$ & 90 \\
\hline & $1 \cdot 0$ & 0.5 & 70 & 20 & 30 \\
\hline & 25 & 0.5 & 37 & 35 & 50 \\
\hline \multirow[t]{2}{*}{ Thioglycollic acid in urea $(8 \mathrm{M})$} & $1 \cdot 0$ & $0 \cdot 5$ & 70 & 90 & $>95$ \\
\hline & $1 \cdot 0$ & 0.5 & 37 & - & 40 \\
\hline $\begin{array}{l}\text { 2-Mercapto-ethanol and urea } \\
(8 \mathrm{M} ; \mathrm{pH} \mathrm{3 \cdot 0)}\end{array}$ & 10 & $0 \cdot 5$ & 70 & 90 & $>95$ \\
\hline $\begin{array}{l}\text { Hydrochloric acid and urea } \\
(8 \mathrm{M} ; \mathrm{pH} \cdot \mathbf{0})\end{array}$ & 一 & 0.5 & 70 & $<\mathbf{5}$ & $<\mathbf{5}$ \\
\hline $\begin{array}{l}\text { Sodium sulphite in the presence } \\
\text { of cuprammonium sulphate } \\
(0.05 \mathrm{M})\end{array}$ & $\begin{array}{c}12.5 \% \\
(w / v)\end{array}$ & 16 & 37 & $<5$ & $<5$ \\
\hline $\begin{array}{l}\text { Sodium sulphite in the presence } \\
\text { of cuprammonium sulphate } \\
(0.05 \mathrm{M}) \text { and urea }(8 \mathrm{M})\end{array}$ & $\begin{array}{c}12 \cdot 5 \% \\
(w / v)\end{array}$ & 16 & 37 & 40 & 75 \\
\hline
\end{tabular}

no phase darkening of Bacillus cereus spores occurred after $20 \mathrm{hr}$. at $37^{\circ}$ in $100 \mu \mathrm{g}$. lysozyme/ml. Spores incubated first with lysozyme and then with performic acid or thioglycollic acid showed no phase darkening. Unlike lysozyme, the proteolytic enzymes trypsin, $\alpha$-chymotrypsin, pepsin, papain or a mixture of peptidases did not cause phase darkening of oxidized or reduced spores of Bacillus cereus. Irradiation also made spores susceptible to lysozyme, and the effectiveness of irradiation depended on the nature of the suspending medium. For instance, 
ultraviolet radiation was most effective when the suspending medium contained hydrogen peroxide, whereas high-speed electrons were most effective when the medium contained thioglycollic acid. The differences due to the suspending media were not further investigated, but the interesting fact is that, under certain conditions, spores were sensitized to lysozyme by irradiation.

The rates of phase darkening varied when any of these experiments were repeated with spores of different organisms, with different stocks of the same spores or at different times; however, the same trends were always shown. For instance, performic acid-treated spores of Bacillus cereus when incubated with lysozyme sometimes showed a lag phase before the onset of phase darkening, but this effect may have been due to slight differences in warming-up time or in sampling time in different experiments. Differences in rate were not considered important and were not investigated further.

Table 2. Re-oxidation of Bacillus cereus spores treated with thioglycollic acid

Spores were reduced by incubation in thioglycollic acid $(1 \%, \mathrm{v} / \mathrm{v})$ and urea $(8 \mathrm{M})$ for $\mathrm{I} \mathrm{hr}$. at $37^{\circ}$, and were re-oxidized by dialysis against distilled water at $4^{\circ}$. Before incubation in lysozyme $\left(100 \mu \mathrm{g} . / \mathrm{ml}\right.$. in $\mathrm{pH} 8.0$ phosphate buffer at $\left.37^{\circ}\right)$ less than $5 \%$ spores were phase dark.

$$
\begin{gathered}
\text { Re-oxidation } \\
\text { time (days) }
\end{gathered}
$$

0

3

14 $\overbrace{15 \mathrm{~min} .}^{\text {Phase dark spores }(\%) \text { in lysozyme after }}$

50

$20 \quad 40$

10

1020

Re-oxidization of spores treated with reducing agents. Table 2 shows that spores sensitized to lysozyme with thioglycollic acid gradually became insensitive during incubation in aerated water. Spores treated with 2-mercapto-ethanol, behaved similarly, but spores oxidized with performic acid remained sensitive to lysozyme after dialysis against water for 2 weeks.

Sensitization of spores to hydrogen peroxide. During attempts to re-oxidize thioglycollic acid-treated spores with hydrogen peroxide it was found that the hydrogen peroxide caused pronounced phase darkening of the treated spores. It was also found that agents which sensitized spores to lysozyme (Table 1) also sensitized them to hydrogen peroxide. Ultraviolet irradiation more effectively sensitized spores to peroxide than to lysozyme and, as with lysozyme, the effectiveness of the treatment depended on the constituents of the suspending medium. Initially hydrogen peroxide caused phase darkening of spores similar to the effect of lysozyme, but on further incubation the spores were almost completely lysed, leaving only shadow forms. Hydrogen peroxide caused phase darkening of spores treated with thioglycollic acid or performic acid at concentrations of $0 \cdot 04-4 \cdot 0 \mathrm{M}$ (pH 8.0; Table 3).

Effect of lysozyme and hydrogen peroxide on Bacillus and Clostridium spores treated with thioglycollic acid. Spores of the following thirteen strains of Bacillus species, which include those which normally split the spore wall and those which normally 
Table 3. Influence of hydrogen peroxide concentration on phase darkening of Bacillus cereus spores treated with performic acid and thioglycollic acid

Spores were treated with performic acid or thioglycollic acid $(25 \%, \mathrm{v} / \mathrm{v})$ at $37^{\circ}$ for $1 \mathrm{hr}$. Before incubation with hydrogen peroxide (in $\mathrm{pH} 8.0$ phosphate buffer at $37^{\circ}$ ) less than $5 \%$ spores were phase dark.

\begin{tabular}{|c|c|c|c|c|}
\hline \multirow[b]{2}{*}{ Reagent } & \multirow{2}{*}{$\begin{array}{c}\text { Hydrogen } \\
\text { peroxide } \\
\text { concentration } \\
(\mathbf{M})\end{array}$} & \multicolumn{3}{|c|}{ Phase dark spores (\%) after } \\
\hline & & $15 \mathrm{~min}$. & $60 \mathrm{~min}$. & $3.5 \mathrm{hr}$ \\
\hline \multirow[t]{4}{*}{ Performic acid } & $4 \cdot 0$ & - & $>95$ & $>\mathbf{9 5}$ \\
\hline & $0 \cdot 4$ & - & 80 & $>95$ \\
\hline & $0 \cdot 04$ & - & 70 & $>95$ \\
\hline & 0 & $<5$ & $<5$ & $<5$ \\
\hline \multirow[t]{4}{*}{ Thioglycollic acid } & $4 \cdot 0$ & $>95$ & $>95$ & $>95$ \\
\hline & $0 \cdot 4$ & 95 & $>95$ & $>95$ \\
\hline & 0.04 & 50 & $>95$ & $>95$ \\
\hline & 0 & $<5$ & $<5$ & $<\mathbf{5}$ \\
\hline
\end{tabular}

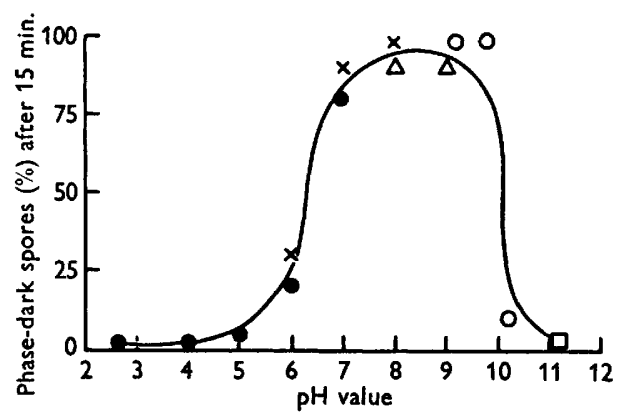

Fig. 1

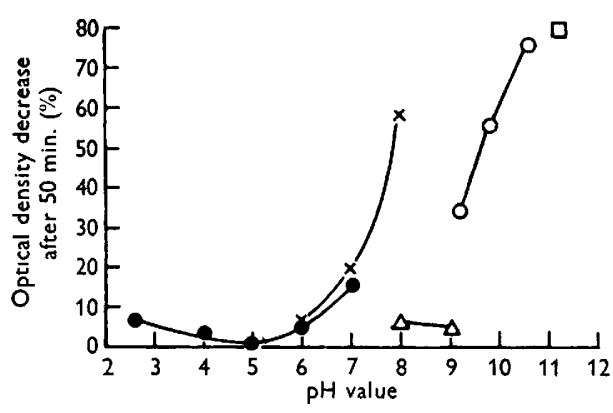

Fig. 2

Fig. 1. Effect of $\mathrm{pH}$ value on lysozyme-induced phase darkening of sensitized spores of Bacillus cereus. Spores were treated with thioglycollic acid $(25 \%, \mathrm{v} / \mathrm{v})$ at $70^{\circ}$ for $30 \mathrm{~min}$. After washing, the spores were incubated in lysozyme $\left(100 \mu \mathrm{g} . / \mathrm{ml}\right.$.) at $37^{\circ}$ in the following buffers: $O$, Mcllvaine; $\times$, phosphate; $\triangle$, tris; $O$, carbonate + bicarbonate; $\square$, carbonate + sodium hydroxide.

Fig. 2. Effect of pH value on hydrogen peroxide-induced lysis of sensitized spores of Bacillus cereus. Spores were treated with thioglycollic acid $(25 \%, v / v)$ at $70^{\circ}$ for 30 min. After washing, the spores were incubated in hydrogen peroxide $(0 \cdot 4 \mathrm{M})$ at $37^{\circ}$ in the following buffers: $\odot$, McIlvaine; $\times$, phosphate; $\triangle$, tris; 0 , carbonate + bicarbonate; $\square$, carbonate + sodium hydroxide. Optical densities were read at $580 \mathrm{~m} \mu$.

lyse most of the spore wall during emergence (Gould, 1962) were treated with thioglycollic acid: B. subtilis strains CX, м2, aterrimus NCTC 2590, niger (syn. B.globigii); B. licheniformis NCTC $7589 ; B$. fusiformis NCTC $2608 ; B$. brevis $\mathrm{NCTC} 7577$; B. mesentericus NCTC $2597 ; B$. polymyxa м $1 ; B$. megaterium E $9 ; B$. cereus strains PX, MP 1, s 20. All became sensitive to lysozyme and to hydrogen peroxide. Spores of the following five Clostridia were similarly sensitized: C. butyricus NCTC 9423; C. saccharobutyricum 103; C. bifermentans $4 \mathrm{AM} ;$ C. multifermentans w 8 ; C. septicum. These reactions thus appeared to be general in their effects on bacterial spores.

Effect of $\mathrm{pH}$ value on the sensitization of spores to lysozyme and hydrogen peroxide. The sensitization of spores to lysozyme and hydrogen peroxide by thioglycollic acid, 
2-mercapto-ethanol and performic acid (all $10 \%, \mathrm{v} / \mathrm{v}$ at $70^{\circ}$ for $30 \mathrm{~min}$.) was tested in the range $\mathrm{pH} 2$ to 7 . Sensitization occurred only at $\mathrm{pH} 2$ or 3. Alkaline thioglycollate $\left(10 \%, \mathrm{v} / \mathrm{v}\right.$ at $70^{\circ}$ for $30 \mathrm{~min}$.) was also tested; sensitization to lysozyme occurred at $\mathrm{pH} 11$ and 12, being most rapid at $\mathrm{pH}$ 12. Alkaline treatment in the absence of thioglycollate did not render spores sensitive to lysozyme. At pH 13 slight phase darkening was caused by alkalinity alone.

Table 4. Release of dipicolinic acid during lysozyme-induced phase darkening of sensitized Bacillus cereus spores

Spores (2.5 mg. dry weight/ml.) were treated with thioglycollic acid $(1 \%, \mathrm{v} / \mathrm{v})$ in the presence of urea $(8 \mathrm{M})$ at $37^{\circ}$ for $1 \mathrm{hr}$. Lysozyme was used at $100 \mu \mathrm{g} . / \mathrm{ml}$. in $\mathrm{pH} \mathrm{8.0} \mathrm{phos-}$ phate buffer at $37^{\circ}$.

$\begin{array}{lrrrrr}\text { Incubation time in lysozyme (min.) } & 0 & 15 & 30 & 60 & 120 \\ \text { Phase dark spores (\%) } & <5 & 50 & 75 & 90 & 90 \\ \text { Spore-bound dipicolinic acid } & 210 & 205 & 110 & 85 & 85\end{array}$
( $\mu \mathrm{g} . / \mathrm{ml}$. suspension)

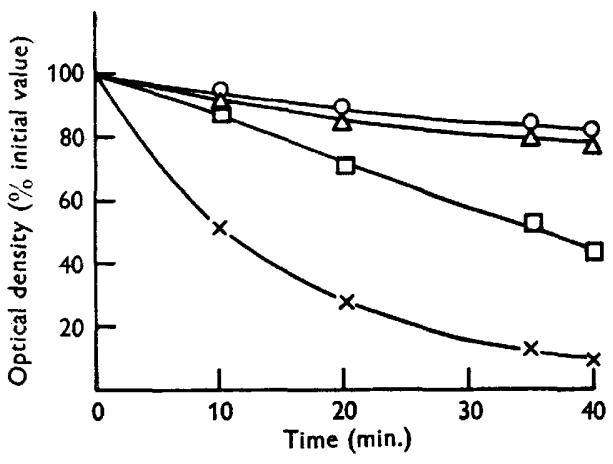

Fig. 3

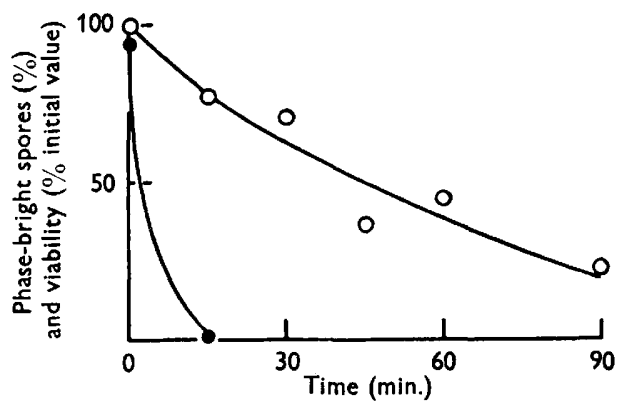

Fig. 4

Fig. 3. Stimulatory effect of metal ions on hydrogen peroxide-induced lysis of sensitized spores of Bacillus cereus. Spores were treated with thioglycollic acid $(10 \%, \mathrm{v} / \mathrm{v})$ at $70^{\circ}$ for $30 \mathrm{~min}$. After washing, the spores were incubated at $37^{\circ}$ in hydrogen peroxide $(0 \cdot 4 \mathrm{M})$ and phosphate buffer $(\mathrm{pH} \mathrm{6.0)}$ with or without the following metal ions $(200 \mu \mathrm{M})$ : $O$, control; $\triangle, \mathrm{Fe}^{2+}, \mathrm{Ni}^{2+}, \mathrm{Fe}^{3+}, \mathrm{Zn}^{2+}, \mathrm{Mn}^{2+} ; \square, \mathrm{Co}^{2+} ; \times, \mathrm{Cu}^{2+}$. Optical densities were read at $580 \mathrm{~m} \mu$.

Fig. 4. Viability of thioglycollic acid-treated spores of Bacillus cereus during phase darkening in lysozyme. Spores were treated with thioglycollic acid $(1 \%, v / v)$ in 8 m-urea for $2.5 \mathrm{hr}$. at $37^{\circ}$ then washed and transferred to lysozyme $(1 \mathrm{mg} . / \mathrm{ml}$.) in phosphate buffer (pH 8) at $37^{\circ}$ : $\bigcirc$, viable count;, phase-dark spores.

Effect of $\mathrm{pH}$ value on phase darkening of spores induced by lysozyme or hydrogen peroxide. The effects of lysozyme and hydrogen peroxide at different $\mathrm{pH}$ values were compared using spores which had been treated with thioglycollic acid. Figure 1 shows that lysozyme was active between $\mathrm{pH} 6 \cdot 0$ and $10 \cdot 0$. Hydrogen peroxide (Fig. 2) was very active even at $\mathrm{pH} \mathbf{1 1 \cdot 2}$ and was relatively inactive below $\mathrm{pH} \mathbf{7 \cdot 0 .}$

Unlike the lysozyme reaction the hydrogen peroxide reaction depended on the nature of the buffer (Fig. 2); e.g. it was inhibited in tris buffer (pH 8.0, 9.0) and it was slower in carbonate + bicarbonate buffer at $\mathrm{pH} 9 \cdot 2$ than in phosphate buffer at pH 8.0. Since tris and carbonate + bicarbonate buffers are sequestrants it seemed probable that metal ions were involved. This was confirmed when the addition of 
various metal ions was found to annul the inhibitory effect of tris and carbonate + bicarbonate buffers and stimulated the reaction at $\mathrm{pH} 6.0$ in phosphate buffer (Fig. 3). Furthermore, ethylene diaminetetra-acetic acid strongly inhibited the hydrogen peroxide reaction in phosphate at $\mathrm{pH} 8 \cdot 0$.

Release of dipicolinic acid during phase darkening of sensitized spores in lysozyme. During normal germination bacterial spores lose all their dipicolinic acid at the same time as phase darkening occurs. It was therefore of interest to measure the loss of dipicolinic acid from treated spores incubated with lysozyme. During thioglycollic acid treatment at $70^{\circ}$ about one-seventh of the spore dipicolinic acid was shed, and Table 4 shows that during phase darkening in the presence of lysozyme a further rapid loss occurred. In this respect the change induced by lysozyme was similar to the change which accompanies normal germination.

Viability of spores during treatment with thioglycollic acid and during subsequent phase darkening in lysozyme. Bacillus cereus spores were incubated in thioglycollic acid ( $1 \%, \mathrm{v} / \mathrm{v} ; 8 \mathrm{~m}$-urea) at $37^{\circ}$ for $24 \mathrm{hr}$. Samples were taken at intervals and spore viability determined by plate count. Although the spores became sensitive to lysozyme within $90 \mathrm{~min}$., no decrease of viability occurred during $24 \mathrm{hr}$. Figure 4 shows that loss of viability occurred at a much slower rate than loss of phase brightness.

\section{DISCUSSION}

Sensitization of cells by disulphide rupture to enzymes other than lysozyme includes the lysis of HeLa cells by trypsin (Shepherd \& Sanders, 1962), release of deoxyribonucleic acid from mammalian sperm by trypsin (Borenfreund, Litt \& Bendich, 1961) and release of deoxyribonucleic acid from vaccinia virus by a protease from Streptomyces griseus (Pfau \& McCrea, 1962). These examples, together with Vinter's (1960) observation of the high disulphide bond content of spore coat fractions strongly suggest that rupture of disulphide bonds is the mode of action of the chemical and physical agents which sensitize bacterial spores to lysozyme or hydrogen peroxide.

The stimulating effect of urea shown in Table 1 can be explained by its action in breaking hydrogen bonds or weakening hydrophobic bonds (Whitney \& Tanford, 1962), thus allowing further opening out of macro-molecular structure, and the re-oxidation of reduced spores in water is easily explained by the well known re-oxidation of thiol groups in reduced proteins to disulphide bonds (Isemura et al. 1961). Spores oxidized with performic acid were found to be stable; this was expected since sulphonate groups formed by oxidation of disulphide bonds are unaffected by storage in aerated water. The whole process of sensitization can therefore be regarded as a disclosure of previously protected sites in the spore which are sensitive to lysozyme or hydrogen peroxide. Why the sensitization reactions are $\mathrm{pH}$ sensitive is not known. The effect of $\mathrm{pH}$ value is certainly on the spore rather than on the reagent, for the three reagents tested all showed the same optimum effect at about $\mathrm{pH}$ 3. Electrophoretic studies of spores by Douglas (1957) showed that near $\mathrm{pH} 3$ the net charge on the spore is zero. It therefore seems likely that the $\mathrm{pH}$ value affects the accessibility and/or reactivity of disulphide bonds in the sporecoat protein. That proteolytic enzymes did not cause phase darkening of sensitized spores does not necessarily mean that their substrates were not present or made 
available, because these substrates need not be involved in maintaining phase brightness. The lysozyme substrate, however, is known to be present in spores because Strange \& Dark (1956) showed that mucopeptide exuded from germinating spores contained lysozyme-sensitive linkages. It is more difficult to suggest a substrate for hydrogen peroxide but the fact that it almost dissolves sensitized spores suggests that its action is relatively non-specific and similar to its solubilizing action on collagen treated with reagents which break hydrogen bonds (Courts, 1961). This is also suggested by the $\mathrm{pH}$ activity curve and the response to metal ions.

The simplest interpretation of the results is that: (1) the outer layer(s) of the spore contains protein with a high disulphide bond content; (2) beneath the proteinaceous layer(s) is lysozyme-sensitive mucopeptide; (3) beneath this, or associated with it, is dipicolinic acid which is released when the mucopeptide is acted on by lysozyme; (4) surrounded by all these components is the dormant pre-vegetative form or core. This interpretation is compatible with other work. For instance, Ohye \& Murrell (1962) and Warth, Ohye \& Murrell $(1963 a, b)$ suggested that lysozyme-sensitive mucopeptide in spores is located in the cortex, the region between the coat and the core which is probably also the site of dipicolinic acid and calcium (Knaysi, 1961; Rode, Lewis \& Foster, 1962). Since rupture of the mucopeptide causes phase darkening, a characteristic and early event in normal germination, the importance of the cortex in maintaining phase brightness of spores is clearly indicated. Phase brightness of spores is probably due to their high solid content (Ross \& Billing, 1957). Loss of phase brightness during germination or lysozyme treatment involves a loss of material with a consequent change in the structure of the cortex followed by replacement of this shed material by water.

Keratin-like proteins are known in micro-organisms; Nickerson \& Falcone (1956) demonstrated a pseudokeratin in yeast cell walls and Schaechter \& Santomassino (1962) suggested that disulphide bonds are involved in maintaining the integrity of growing cells of Escherichia coli. Vinter $(1961 a, b, 1962)$ showed that radiation resistance of spores probably depends on the high concentration of cystine disulphide bonds in the spore coat fraction. Disulphide-rich proteins are typically fibrous, insoluble and resistant to heat or enzymes. For instance, disulphide bonds render insulin partially resistant to chymotrypsin (Ryle, Sanger, Smith \& Kitai, 1955).

Apart from their protective role, Vinter (1960) suggested that spore disulphide bonds may play a more active part during germination and he demonstrated a qualitative reduction of disulphide bonds to sulphydryl groups during germination (Vinter, $1961 b$ ). Normal germination may involve enzymic rupture of spore disulphide bonds with enzymes similar to protein disulphide reductases (Hatch \& Turner, 1960; Nickerson \& Falcone, 1956) perhaps using reducing power from the metabolism of substances which initiate germination. It is clear that reagents which rupture disulphide bonds do not themselves initiate germination, although they leave the normal germination capacity and viability unimpaired. However, the action of a lytic system such as that discovered by Strange \& Dark (1957) on mucopeptide in the spore cortex (Ohye \& Murrell, 1962) could change the permeability (Black \& Gerhardt, 1962), leading to swelling of the spore with stretching of the weakened coat (Hitchins et al. 1963). It is interesting to speculate that this stretching could be similar to the plastic deformation of budding points on yeast cell walls which is thought to be due to reduction of cell wall disulphide bonds by 
protein disulphide reductase (Nickerson \& Falcone, 1959). Such endogenous spore enzyme systems would clearly be similar in effect to the exogenous systems described in this work.

We wish to thank Mr A. W. Knight and Mr B. A. Wright for valuable assistance, and Dr A. Hurst for advice and encouragement.

\section{REFERENCES}

Black, S. H. \& Gerhardt, P. (1962). Permeability of bacterial spores IV. Water content uptake and distribution. J. Bact. 83, 960.

Borenfreund, E., Litt, E. \& Bendich, A. (1961). Isolation and properties of deoxyribonucleic acid from mammalian sperm. Nature, Lond. 191, 1375.

Courts, A. (1961). Structural changes in collagen 2. Enhanced solubility of bovine collagen: reactions with hydrogen peroxide and some properties of soluble eucollagen. Biochem. J. 81, 356.

Douglas, H. W. (1957). Electrophoretic studies on spores and vegetative cells of certain strains of B. megaterium, B. subtilis and B. cereus. J. appl. Bact. 20, 390.

Epstein, C. J. \& Anfinsen, C. B. (1962). The reversible reduction of disulphide bonds in trypsin and ribonuclease coupled to carboxymethyl-cellulose. J. biol. Chem. 237, 2175.

Fruton, J. S. \& Simmonds, S. (1958). General Biochemistry, p. 705, New York: John Wiley and Sons, Ltd.

Gibss, B. M. \& Hirsch, A. (1956). Spore formation by Clostridium species in an artificial medium. J. appl. Bact. 19, 129.

GouLd, G. W. (1962). Microscopical observations on the emergence of cells of Bacillus spp. from spores under different cultural conditions. J. appl. Bact. 5, 35.

Gould, G. W. \& Hitchrns, A. D. (1963). Sensitization of bacterial spores to lysozyme and hydrogen peroxide with reagents which rupture disulphide bonds. Nature, Lond. $197,622$.

Hatch, M. D. \& Turner, J. F. (1960). A protein disulphide reductase from pea seeds. Biochem. J. 76, 556.

Hitchins, A. D., Gould, G. W. \& Hunst, A. (1963). The swelling of bacterial spores during germination and outgrowth. J. gen. Microbiol. 30, 445.

Isemura, T., TAKagi, 'T., MAeda, Y. \& ImaI, K. (1961). Recovery of enzymatic activity of reduced taka-amylase $\mathrm{A}$ and reduced lysozyme by air oxidation. Biochem. biophys. Res. Commun. 5, 373.

Jansen, F. W., Lund, A. J. \& Anderson, L. E. (1958). Colorimetric assay for dipicolinic acid in spores. Science, 127, 26.

KNAYSI, G. (1961). Determination, by spodography, of the intracellular distribution of mineral matter throughout the life history of Bacillus cereus. J. Bact. 82, 556 .

KонN, A. (1960). Lysis of frozen and thawed cells of Escherichia coli by lysozyme, and their conversion into sphaeroplasts. J. Bact. 79, 697.

Mackie and McCartney's Handbook of Bacteriology (1960). 10th ed. R. Ed. Cruickshank. Edinburgh: E. and S. Livingstone, Ltd.

MURRell, W. G. (1961). Spore formation and germination as a microbial reaction to the environment. In Microbial Reaction to Environment: Symp. Soc. gen. Microbiol. 11, 100.

Nickerson, W. J. \& Falcone, G. (1956). Enzymatic reduction of disulphide bonds in cell wall protein of baker's yeast. Science, 124, 318.

Nickerson, W. J. \& Falcone, G. (1959). The function of protein disulphide reductase in cellular division of yeasts. In Sulfur in Proteins, p. 409. Ed. by R. Benesch et al. New York and London: Academic Press, Inc.

Noller, E. C. \& Hartsell, S. E. (1961). Bacteriolysis of Enterobacteriacae. I. Lysis by four lytic systems using lysozyme. J. Bact. 81, 482.

Ohye, D. F. \& Murreld, W. G. (1962). Formation and structure of the spores of Bacillus coagulans. J. cell. Biol. 14, 111. 
Pfau, C. J. \& McCrea, J. F. (1962). Release of deoxyribonucleic acid from vaccinia virus by 2-mereapto-ethanol and Pronase. Nature, Lond. 194, 894.

Repaske, R. (1956). Lysis of Gram-negative bacteria by lysozyme. Biochim. biophys. Acta, 22, 189.

Rode, L. J., Lewis, C. W. Jr. \& Foster, J. W. (1962). Electron microscopy of spores of Bacillus megaterium with special reference to the effects of fixation and thin sectioning. J. cell. Biol. 13, 423.

Ross, K. F. A. \& Billing, E. (1957). Water and solid content of living bacterial spores and vegetative cells as indicated by refractive index measurements. J. gen. Microbiol. 16, 418.

Ryle, A. P., Sanger, F., Smith, L. F. \& Kitai, R. (1955). The disulphide bonds of insulin. Biochem. J. 60, 541 .

Salton, M. R. J. \& Marshall, B. J. (1959). The composition of the spore wall and the wall of vegetative cells of Bacillus subtilis. J. gen. Microbiol. 21, 415.

SANGER, F. (1947). Oxidation of insulin by performic acid. Nature, Lond. 160, 295.

Schaechter, M. \& Santomassino, A. (1962). Lysis of Escherichia coli by sulphyldrylbinding reagents. J. Bact. 84, 318.

Sela, M., White, F. H. Jr. \& Anfinsen, C. B. (1957). Reductive cleavage of disulphide bridges in ribonuclease. Science, 125, 691.

Shepherd, G. R. \& Sanders, P. C. (1962). The complementary effects of 2-mercaptoethanol and trypsin in the lysis of HeLa cells. J. cell. Biol. 14, 346.

Strange, R. E. \& Dark, F. A. (1956). The composition of the spore coats of Bacillus megaterium, B. subtilis, and B. cereus. Biochem. J. 62, 459.

Strange, R. E. \& Dark, F. A. (1957). A cell-wall lytic enzyme associated with spores of Bacillus species. .J. gen. Microbiol. 16, 236.

Swan, J. M. (1957). Thiols, disulphides and thiosulphates: some new reactions and possibilities in peptide and protein chemistry. Nature, Lond. 180, 643.

VINTER, V. (1960). Spores of microorganisms VIII. The synthesis of specific calcium and cystine containing structures in sporulating cells of bacilli. Folia Microbiol. 5, 217.

VINTER, V. (1961 a). Changes in radioresistance of sporulating cells of Bacillus cereus. Nature, Lond. 189, 589.

VinTER, V. $(1961 b)$. The formation of cystine-rich structure in sporulating cells and its possible role in the resistance of spores. In Spores II. Ed. H. O. Halvorson. Minneapolis, 15. Minn.: Burgess Publishing Co.

VinTER, V. (1962). Spores of microorganisms IX. Gradual development of resistant structure of bacterial endospores. Folia Microbiol. 7, 115.

Warren, G. H., Gray, J. \& Bartell, P. (1955). The lysis of Pseudomonas aeruginosa by lysozyme. J. Bact. 70, 614.

Warth, A. D., Ohye, D. F. \& Murrell, W. G. (1963a). The composition and structure of bacterial spores. J. cell. Biol. 16, 579.

WArth, A. D., Ohye, D. F. \& MUrRell, W. G. (1963b). Location and composition of spore mucopeptide in Bacillus species. J. cell. Biol. 16, 593.

Whitney, P. L. \& Tanford, C. (1962). Solubility of amino acids in aqueous urea solutions and its implications for the denaturation of proteins by urea. J. biol. Chem. 237, 1735. 